\title{
Integrating Malaysian and Japanese Textile Motifs Through Product Diversification: Home Décor
}

\author{
Muhammad Fitri Samsuddin ${ }^{1}$, Azni Hanim Hamzah², Fazlina Mohd Radzi ${ }^{3}$, \\ Siti Nurul Akma Ahmad ${ }^{4}$, Mohd Faizul Noorizan ${ }^{6}$, Mohd Ali Azraie Bebit ${ }^{6}$ \\ ${ }^{12356}$ Faculty of Art \& Design, Universiti Teknologi MARA Cawangan Melaka \\ ${ }^{4}$ Faculty of Business \& Management, Universiti Teknologi MARA Cawangan Melaka \\ Authors' email: 'muhammadfitri@uitm.edu.my; ${ }^{2}$ aznihanimhamzah@uitm.edu.my; \\ 3azlinamohdradzi@uitm.edu.my; ${ }^{4}$ sitinu8498@uitm.edu.my; ${ }^{5}$ mohdfaizulnoorizan@uitm.edu.my; \\ 6aliazraie@uitm.edu.my
}

Published: 28 September 2020

\begin{abstract}
Malaysian textile motifs especially the Batik motifs and its product are highly potential to sustain in a global market. The integration of intercultural design of Malaysian textile motifs and Japanese textile motifs will further facilitate both textile industries to be sustained and demanded globally. Besides, Malaysian and Japanese textile motifs can be creatively design on other platforms not limited to the clothes. Therefore, this study is carried out with the aim of integrating the Malaysian textile motifs specifically focuses on batik motifs and Japanese textile motifs through product diversification. This study focuses on integrating both textile motifs and diversified the design on a home décor including wall frame, table clothes, table runner, bed sheets, lamp shades and other potential home accessories. In this concept paper, literature search was conducted to describe about the characteristics of both Malaysian and Japanese textile motifs and also to reveal insights about the practicality and the potential of combining these two worldwide known textile industries. The investigation was conducted to explore new pattern of the combined textiles motifs. The new combined pattern is visually presented as an outcome of this study. An integration of Malaysian and Japanese textile motif aims to strategize the coverage of Malaysian and Japanese textile motifs in a global market. This idea may also contribute to the new opportunities for Malaysian and Japanese textile producers in expanding their design not merely on the clothes fabric but also towards the home decor fabric design. This will turn into additional profit making and increasing economic growth of both countries as well as expanding the traditional textiles industry.
\end{abstract}

Keywords: Malaysian Textile Motifs, Japanese Textile Motifs, Batik Motifs, Home Decor

eISSN: 2550-214X (C) 2020. The Authors. Published for Idealogy Journal by UiTM Press. This is an Open Access article distributed under the terms of the Creative Commons Attribution-NonCommercial-NoDerivatives License (http://creativecommons.org/licenses/by-nc-nd/4.0/), which permits non-commercial re-use, distribution, and reproduction in any medium, provided the original work is properly cited, and is not altered, transformed, or built upon in any way.

\section{INTRODUCTION}

In a view of Malaysian textile motifs, Batik is one of the most dominant textile industries. Thus, in this study the Malaysian textile motifs are specifically focused on the batik motifs as to represent the most dominant textile motifs. Malaysia holds a potential batik industry that has long established as a domestic industry which being crafted by the local people. This domestic industry is expected to benefits the batik producer to increase their monthly income and living standard. However, existing literature reveals this potential industry are still using conventional promotion strategy through exhibitions and personal selling on their batik product which mostly focuses on garments (Muhammad Fitri, et.al. 2019; Rahab et al., 2013). There is still limited marketing strategy which conventionally carried out by most of craftsmen which targeted among the local people. Thus, greater marketing strategy and promotion should be extended to other medium or platforms to reach a wider targeted audience, even towards inter-industry marketing including the interior design, automotive or any other potential sector. Likewise, sustainable issues of batik production can be addressed by extending its 
motifs on the new platform. These days with the advancement of innovation and creative ideas, batik industry is also highly potential to be expanded in a global market. Past study concluded that Batik motif has high potential to be applied on other medium not limited to the garments (Muhammad Fitri, et.al. 2019, Wardani \& Sitindjak. 2014). Previous studies have proposed the diversification of batik motif on various medium including applying the natural batik motifs in porcelain wares (Ahmad Sayuti, et.al. 2018), batik motifs as interior design of Malaysia public transports (Muhammad Fitri, et.al. 2019) and integrating Batik motifs into the design structure of the Persian carpet (Tanha and Amad, 2013).

Meanwhile, intercultural study has been in high interest topic among researchers and batik is one of the interest areas. This includes a previous study that was conducted by Kundharu Saddhono, et.al. (2014) which focus on integration of Indonesia Batik and Japan Kimono in fashion industry and also in Tanha and Amad, (2013) study that integrates Batik motifs into Persian carpet design. Past study revealed a potential cultural interaction on Asian countries that support cultural product exchange (Kundharu Saddhono, et.al. 2014) and with batik supremacy the marketing of its product can be expanded internationally (Kundharu Saddhono, et.al. (2014); Supriyadi \& Sariatun, (2016)). Considering its potential, batik handicraft will bring a significant contribution towards district income (Supriyadi \& Sariatun, 2016) as well as national income. Therefore, there is a potential of batik intercultural study that should be emphasized in developing product collaboration for future prospect global market. Thus, this study aims to integrate the Malaysian and Japanese textile motifs through product diversification and its design on a home décor.

\subsection{Development of Batik Industries Malaysia}

Batik Industries in Malaysia has started with a small - scale operations which later turns into a profitable batik fabrication, also as a national endeavour. Malaysian batik is among the famous product both domestically and abroad. Batik is the most well-known craft brand in Malaysia, among every resident and visitor, whether male or female tourist. Moreover, among the corporate buyers, batik is $1 / 3$ in popularity, after pewter and wooden craft products. Malaysian batik is supported by Malaysian Handicraft Development Corporation (Malaysian Handicraft) that serves as governmental efforts to promote batik manufacturing, its advertising and exporting handicraft merchandise.

In the states of Kelantan and Terengganu, where the Batik sector was first provided in 1910, Malaysian Handicraft registered more than 320 batik entrepreneurs with the perfect concentration of batik producers. However, due to its special characteristics, the successful merchandising of Malaysian batik has led to the overseas batik production that imitates Malaysian batik. The national economic system has been affected due to this infringement of the designs and production methods of Malaysian batik by foreign batik producers (Malaysian Handicraft, 2009). Global manufacturers, including batik factories in China, started to create batik printing that mimicked a batik style of Kelantan. China batik fabric, which is normally made of polyester, is documented to cause losses of around RM3 million per year to 200 batik operators (Malaysian Handicraft). Malaysia batik industries are declining as overseas batik is supplied at a lower rate than Malaysian batik's cost. The main reason for its lower rate is that foreign batik manufacturers use printing presses to create the fabric diagram. It makes the production of giant portions of Malaysian batik imitation in a short time as compared to locally hand-painted batik.

\subsection{History of Batik}

Early declaration shows that batik has a long-established position in the Malay Archipelago's clothing culture. Mijer (1919) highlighted that, Javanese Island batik sarongs are predominant and also dominant in other countries including Malaysia. Since $1402-1511$, where Malacca is known as the capital of the Malay Kingdoms, there has been various sort of materials was brought from Asian countries which includes cotton, silk and gold thread that were utilized for the venture.

Batik refers to the fancy textures containing more than a couple of shades and designs. The term 'BATIK' is inferred from the Javanese state 'tick'. The other term was derived from 'Ambatik' which 
mean to sketch, write, paint or drip. Batik designs can be created with the use of a carved block, a screen and hand stroke. These days, Malaysia have produced batik pattern not only for a local garment but also for a variety of batik products. Malaysian batik artisans use hand-drawn techniques which refers to the application of canting on the stretch cotton cloth. Then, the process of design continues with heat wax and fill up with colour to create a texture that suits for the design. The most common motif found in Malaysia are nature and geometric.

\section{LITERATURE REVIEW}

\subsection{Batik Motifs}

Motifs for cloth design have a decorative role, which serves to produce patterns contributing to the object or artefact's aesthetic characteristics. In the Malay handicraft format explored via Ismail (1997) it used to be considered that in batik sarong design 'motifs are composed in two patterns - organic (plants, herbal element, birds, animals) and geometric (pucuk rebung/triangle) and Dong-son geometry' (p. 229). Following the work of Ismail (1997) and Hussin (2006), researched the kind of natural motifs that commonly used in batik and songket.

Table 1: Type of Batik Motif

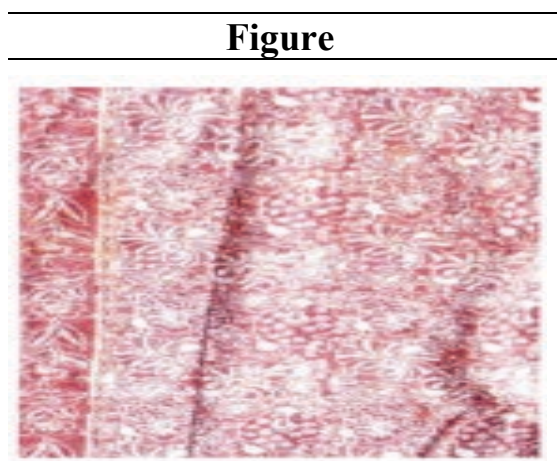

Type of Motif

Floral Motif

Malaysian batik sarong with the daun sirih (betel leaf) motif. The motif that's inferred from plants is constituted from different parts of plants. The magnificence and highlights of plants are chosen from particular components, such as blooms, clears out, shoots, ringlets, natural products and stems. Blooms with their distinctive shapes and colours are favoured motifs.

\section{Geometric Motif/ Malay Dessert Motif}

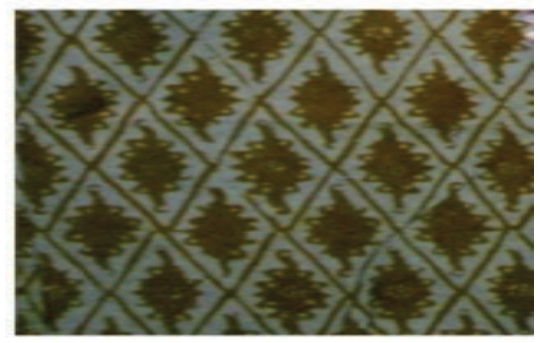

The "badan kain" (the body) filled with the "potong wajik" (sweet glutinous rice cuts - Malay dessert) themes. Malay conventional cuisine could be a source of motivation for motif creation. A few persistently utilized sorts of motif are those that delineate rice, the Malaysian staple nourishment, and Malay pastries. The "bentuk potong wajik" (diamond-shaped cuts of the Malay sweet glutinous rice dessert) were found on a few samples of the batik sarongs.

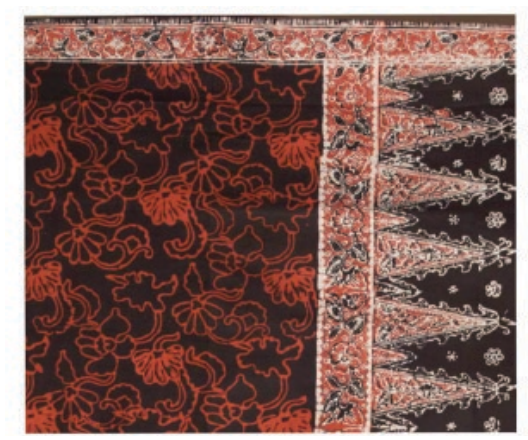

\section{The morning glory motif}

The motif is set at the "apit kain" the "tepi kain" (the mounting border) and (the upper and lower edges). Within the format of batik sarongs, there are motifs organized in vertical path, recognized as the "apit kain" (the surrounding border). They are put to isolated the "kepala kain" (the central board) and the "badan kain" (the bigger cleared out and right boards).

*Photo and drawing by Legino, R. (2012) 


\subsection{History of Bingata / Japanese Textile}

Among the longest known Japanese Textile art is known as Bingata. The history of Bingata and also the history of its production originated in Okinawa, located in the southern tip of the Japanese peninsula. Okinawa was once known as the old Ryukyu kingdom. In ancient times, Bingata was an exclusive textile that could only be used by the royal family. When the Ryukyu Dynasty collapsed, Bingata's production also declined. But over the years, it has become a symbol of Okinawa's resilience in the face of Okinawa's anger against the US after the World War II.

Bingata a textile art using tie and dye technique. Usually, the colours used are bright colours and are only used by certain class. For example, yellow can only be used by the King, the same rule as the use of yellow only for the nobility of the time of the Malay kings in ancient times. Causes of motive often use subjects from nature such as fish, trees and flowers. According to history, the Ryukyu Dynasty has trade history with China, Korea, Japan and Southeast Asia. Therefore, the motifs used had a significant effect, resulting from the assimilation of trade with the former empire outside the southern Ryukyu archipelago.

\subsection{The patterns of Bingata}

The aristocracy wore Bingata made by "Chirimen" (Crepe silk cloth) or "Rinzu" (Satin cloth) with beautiful layers of color, with white or light yellow. For the common people, the type of fabric allowed to wear is a 'oboro-gata' cotton cloth dyed in 5 colors (iro-oboro) or 2 colors (indigo and black). Social class status during the Ryukyu Dynasty was differentiated by wearing formal attire. It is determined by size, pattern, and even color differences also determine one's position at that time, including age and gender. Large size patterns for the royal family, while the smaller size is used by Shizoku (warrior). Today the use of clothing using Bingata textiles is widely used in performing arts and historical reenactments. In particular, yellow Bingata can only be worn by royal families and aristocrats for ceremonies and entertainment occasions. A designer will be hired by royal family to create their own patterns by using the official colors of the royal house. Usually, the pattern that is created will only be used once, so Bingata designers will need to come up with new patterns all the time.

Table 2: Type of Bingata Motif

Type of Motif
leaves, snowflakes, and handballs on a yellow ground.



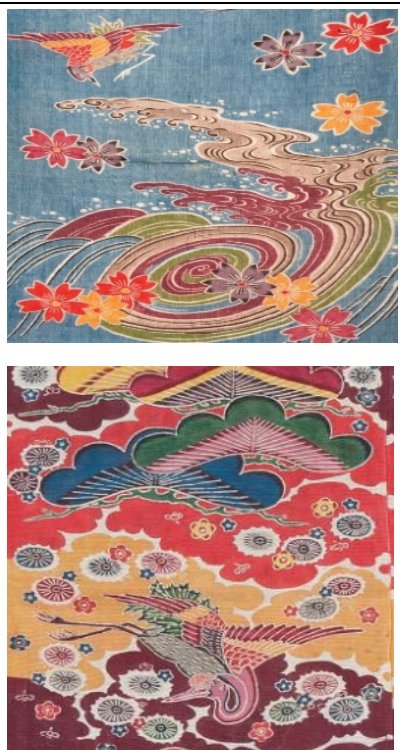

Detail of "tanashi" with waves, cranes and cherry blossoms on a light indigo ground.

"Dujin" (inner robe) with cranes, pine, plum blossoms and chrysanthemums on a multicolour ground.

${ }^{*}$ Photo by Okinawa Churashima Foundation, n.d.

\subsection{Iconic Malaysian Batik Motif}

\subsubsection{Leaves and Flowers Motif}

The foremost prevalent motif are leaves and blooms. Malaysian batik portraying people or creatures are uncommon since Islam standards restrict creature pictures as enhancement. However, the butterfly subject may be a common exemption. The Malaysian batik is additionally famous for its geometrical plans, such as spirals. The strategy of Malaysian batik making is additionally very different from those of Indonesian Javanese batik, the design is bigger and less difficult, it rarely or never employments canting to form complex designs and depend intensely on brush portray strategy to apply colours on textures. The colours moreover tend to be lighter and more dynamic than profound coloured Javanese batik.

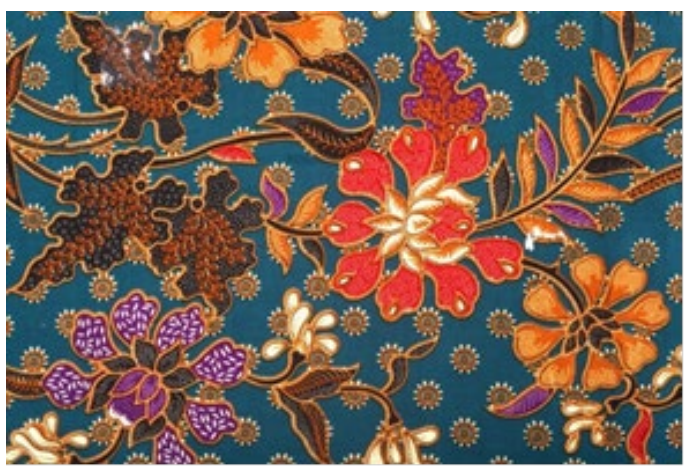

*Photo by Zatul Akma, 2019

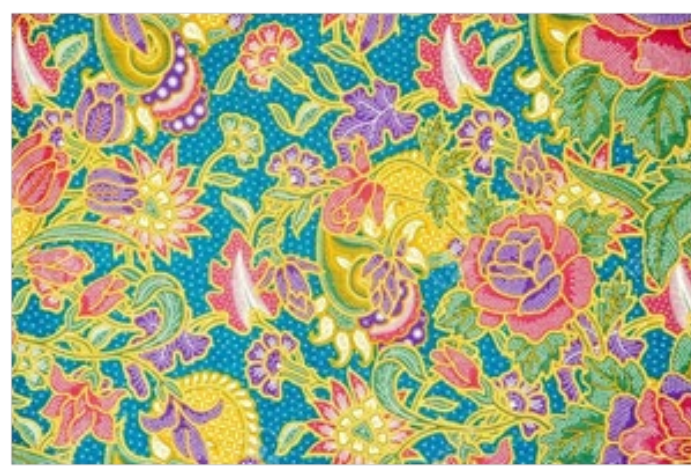

*Photo by Penchan Pumila, n.d.

\subsection{2. 'Pucuk Rebung' Motif}

Figure 1: Leaves and flowers motif

'Pucuk rebung' is a unique Malay motif that had been utilized for long time back and still applying it as a conventional Malay motif. 'Pucuk rebung' may be a fauna motif that impact by the 'rebung' which is known as bamboo shoots. Bamboo shoots are the eatable shoots (unused bamboo culms that come out of the ground) of bamboo species bambusa vulgaris and phyllostachys edulis. They are utilized in various Malay dishes and broths. 'Pucuk Rebung' motif is exceptionally celebrated in Malysian batik making, a part of batik producers utilizes 'Pucuk Rebung' as their trade marks in planning batik material. Underneath is a few near up of bamboo shoots. 


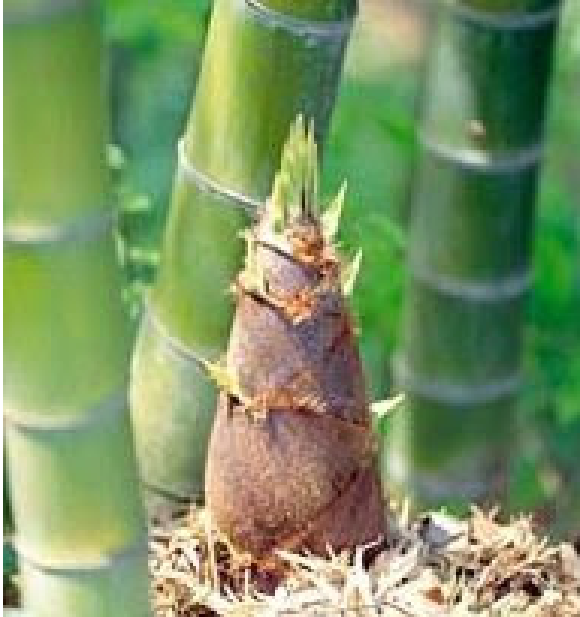

*Photo by Pelapak, n.d.
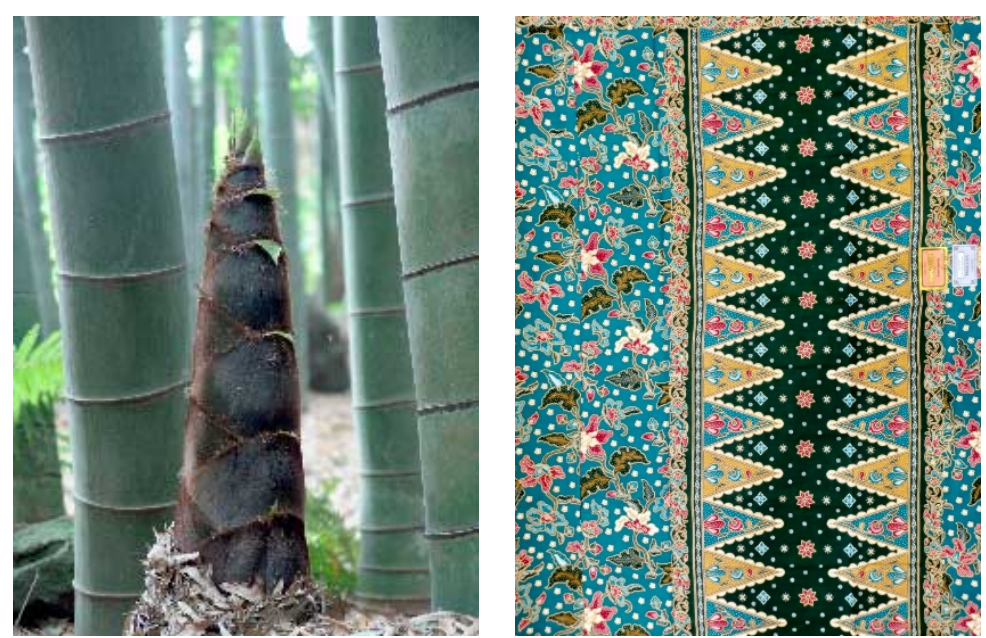

Figure 2: 'Pucuk Rebung' motif

\subsection{Iconic Japanese Textile Motif}

\subsection{1. 'Seigaiha Wave' Motif Furoshiki}

The seigaiha or wave could be a design of layered concentric circles making curves, typical of waves or water and speaking to surges of great good fortune. It can moreover imply power and strength. The wave image or theme was initially utilized in China on antiquated maps to delineate the ocean. In Japan its most punctual appearance was on the clothing of a 6th century haniwa (funerary earthenware clay figure). It proceeded to be utilized as an image on clothing, especially kimonos, for over a thousand years. All through Japan's plan history it has been utilized on kimonos, ceramic product, lacquerware, then later in graphics design.
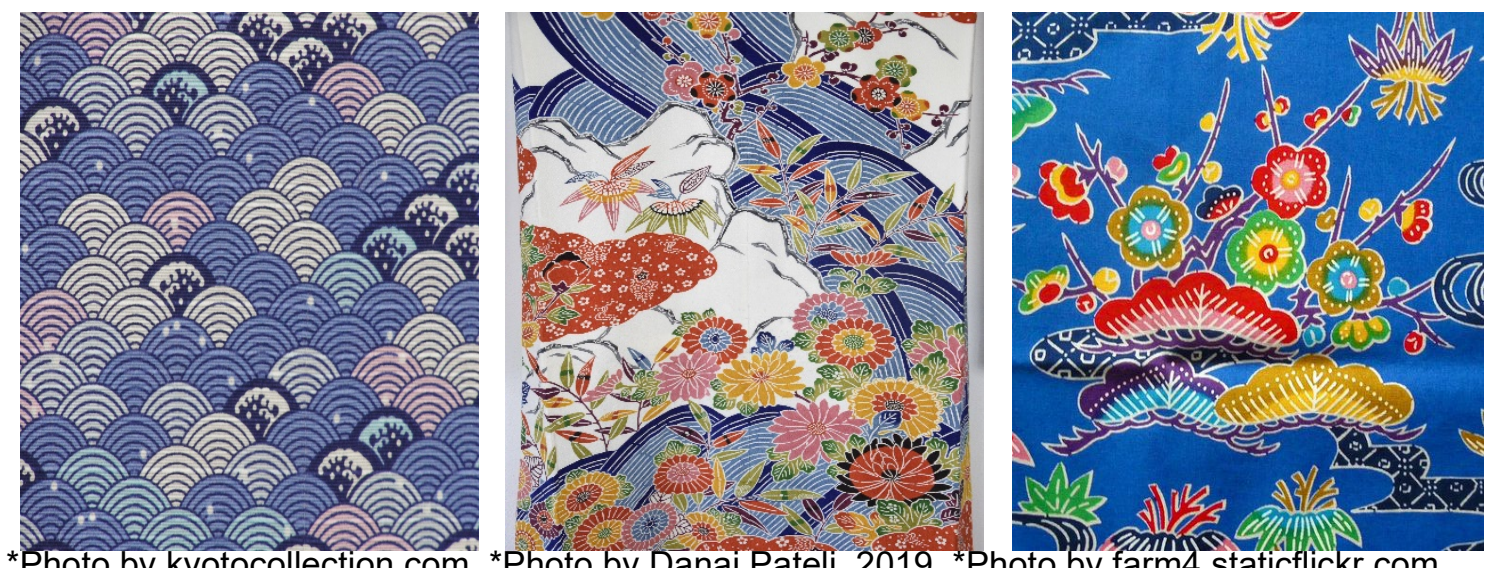

*Photo by kyotocollection.com *Photo by Danai Pateli, 2019 *Photo by farm4.staticflickr.com

Figure 3: 'Seigaha Wave' motif furoshiki (traditional Japanese wrapping cloth)

\section{METHODS}

This concept paper used literature search which was conducted to reveal insights about the practicality and the potential of combining two worldwide known textile industries which are Malaysian textile motifs (represented by batik motifs) and Japanese textile motifs. The literatures were searched from various online databases including Scopus, Science Direct, Research Gates and Google Scholars with the keyword searched includes "Malaysian Textile Motifs", "Japanese Textile Motifs" and "Batik Motifs". The literature searched was leads to the findings of the integration Batik design from past studies as presented in Table 3. The analysis from past studies revealed the potential integration of Batik design into other medium not limited to the garments. This paper is grounded by the result from past 
studies which reveals the potential of batik integration on various platforms. Then, the visual analysis was also conducted to extract the most iconic motif applied in both Malaysian Batik motif and Japanese textile motif as presented in Table 4. The investigation was further conducted to explore new composition of the combined textiles motifs. The draft idea and design sketches were sent to one of the appointed Batik producers to materialize with the actual results as presented in Figure 5. Finally, the new combined design is visually presented as an outcome of this study.

Table 3: Summary of Integration Batik Design

\begin{tabular}{lcl}
\hline \multicolumn{1}{c}{ Author } & Year & \multicolumn{1}{c}{ Integration Idea } \\
\hline Muhammad Fitri, et.al. & 2019 & Batik motifs as interior design of Malaysia public transports \\
Ahmad Sayuti, et.al. & 2018 & Applying the natural batik motifs in porcelain wares \\
Aizat Khairi, et.al. & 2018 & $\begin{array}{l}\text { Batik Application in the development of the fibreglass boat } \\
\text { Tanha \& Amad }\end{array}$ \\
& 2013 & $\begin{array}{l}\text { Integrating Batik motifs into the design structure of the Persian } \\
\text { carpet }\end{array}$ \\
\hline
\end{tabular}

Table 4: Visual Analysis

\begin{tabular}{|c|c|c|c|}
\hline $\begin{array}{l}\text { ICONIC MALAYSIAN BATIK } \\
\text { MOTIF }\end{array}$ & $\begin{array}{l}\text { Malaysian batik portraying people or } \\
\text { creatures are forbidden since Islam } \\
\text { standards restrict creature pictures as } \\
\text { enhancement. } \\
\text { - organic (plants, herbal element, birds, } \\
\text { animals) } \\
\text { geometric (pucukrebung/triangle) } \\
\text { colours moreover tend to be lighter and } \\
\text { more dynamic }\end{array}$ & $\begin{array}{l}\text { ICONIC JAPANESE TEXTILE } \\
\text { MOTIF }\end{array}$ & $\begin{array}{l}\text { The simplified beauty of nature is seen on } \\
\text { fabrics, crafts, and many other places in } \\
\text { Japan } \\
\text { two categories, one is a geometric pattern } \\
\text { derived from natural phenomena } \\
\text { - another based on the designs of animals } \\
\text { and plants. }\end{array}$ \\
\hline $\begin{array}{l}\text { Pucuk Rebung } \\
\text { - an original Malay motif that had been used } \\
\text { for long time ago and still applying it as a } \\
\text { traditional Malay Motif. } \\
\text { - influence by the 'Rebung' which is known } \\
\text { as bamboo shoots } \\
\text { Commonly used in numerous Malay dishes } \\
\text { and broths }\end{array}$ & 1 & $\begin{array}{l}\text { Shippō (Seven Treasures) } \\
\text { - Circles overlapping in quarters } \\
\text { - resemble petals and each center forms a } \\
\text { shining star } \\
\text { - regarded as auspicious for the prosperity of } \\
\text { descendants, good relationships, and for } \\
\text { bringing harmony. }\end{array}$ & \\
\hline $\begin{array}{l}\text { Leaves \& Flowers } \\
\text { - The magnificence and highlights of plants } \\
\text { are chosen from particular components, } \\
\text { such as blooms, clears out, shoots, } \\
\text { ringlets, natural products and stems. } \\
\text { Blooms with their distinctive shapes and } \\
\text { colours are favoured motifs. }\end{array}$ & 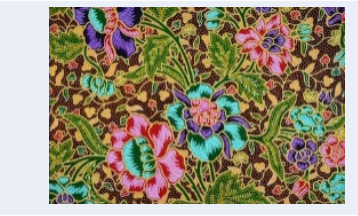 & $\begin{array}{l}\text { Diamond Flower (Hanabishi) \& } \\
\text { Tortoiseshell (Kikkou) Pattern } \\
\text { - pattern of four flower petals in a } \\
\text { diamond shape } \\
\text { - Kikkou literally means "tortoiseshell" in } \\
\text { Japanese } \\
\text { - hexagon pattern and it represents } \\
\text { longevity }\end{array}$ & 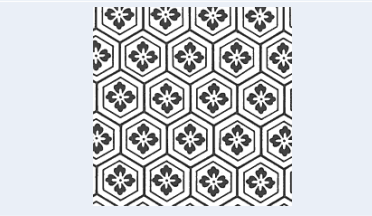 \\
\hline $\begin{array}{l}\text { Geometric Motif/ Malay Dessert Motif } \\
\text { "potong wajik" (sweet glutinous rice cuts - } \\
\text { Malay dessert) themes. } \\
\text { Malay conventional cuisine could be a } \\
\text { source of motivation for motif creation. } \\
\text { "bentuk potong wajik" (diamond-shaped } \\
\text { cuts of the Malay sweet glutinous rice } \\
\text { dessert) were found on a few samples of } \\
\text { the batik sarongs. }\end{array}$ & & $\begin{array}{l}\text { Sayagata (Manji) Pattern } \\
\text { - also knows as Manji } \\
\text { was introduced to Japan along with } \\
\text { Buddhism from China } \\
\text { Manji originated in India and was spread } \\
\text { along with Buddhist teachings throughout } \\
\text { Asia }\end{array}$ & \\
\hline
\end{tabular}




\subsection{Integration of Malaysian \& Japanese Textile Motif}

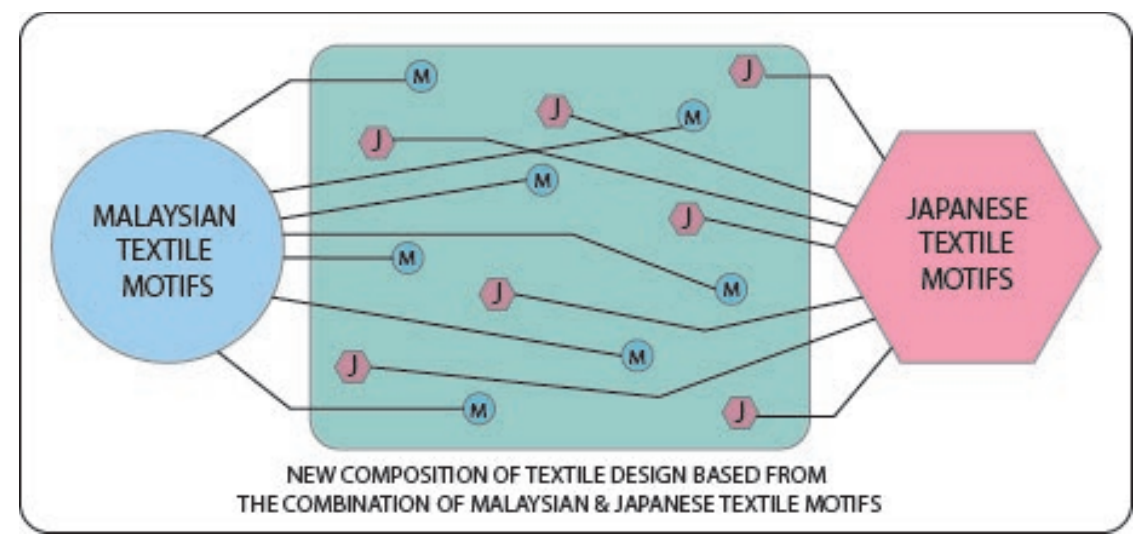

Figure 4: The proposed Integration Concept

Considering the potential of intercultural study on batik, this study focuses on developing the integration idea of two textile industries. The proposed idea is crafted to expand the textile industry collaboration as well as diversified its usage on other medium for potential prospect in a global market.

\section{RESULTS}

The idea is initially crafted by combining the motif from Malaysia Batik and Japanese textile and placing together in pattern composition to see its potential outcome. Based on the commonly used type of Batik motif (Table 1), type of Bingata motif (Table 2) and also visual analysis (Table 4), the iconic motif of both textiles is extracted to be embedded in the integration design. As in Batik motif, the iconic motifs are leaves and flowers and 'Pucuk Rebung' (bamboo shoots) while for Japanese textile the extracted iconic motif is 'Seigaiha Wave'. These iconic motifs are mix together in the proposed design (Figure 5) to create the new composition of pattern. The composed pattern then will be applied on the potential product of home décor as presented in the next section.

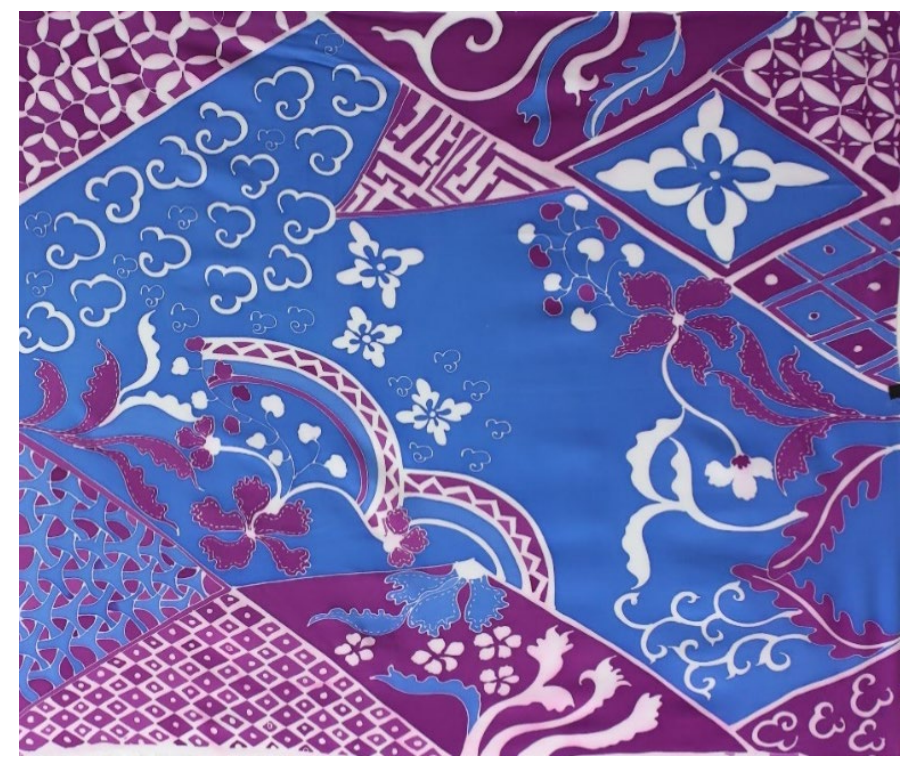

Figure 5: The proposed pattern 


\subsection{Potential of Malaysian Batik and Japanese Textile Motif Integration in Home Decor}

The integration of Malaysian Batik and Japanese textile motif is potentially applied in home décor as a product diversification such as bed runner, lamp shade, curtain and etc. as presented in Figure 5 and Figure 6. The new composition of integration both designs is expected to meet the demands of potential buyer of either individual or home interior designer with the interest of highlighting the traditional identity concept in their design.

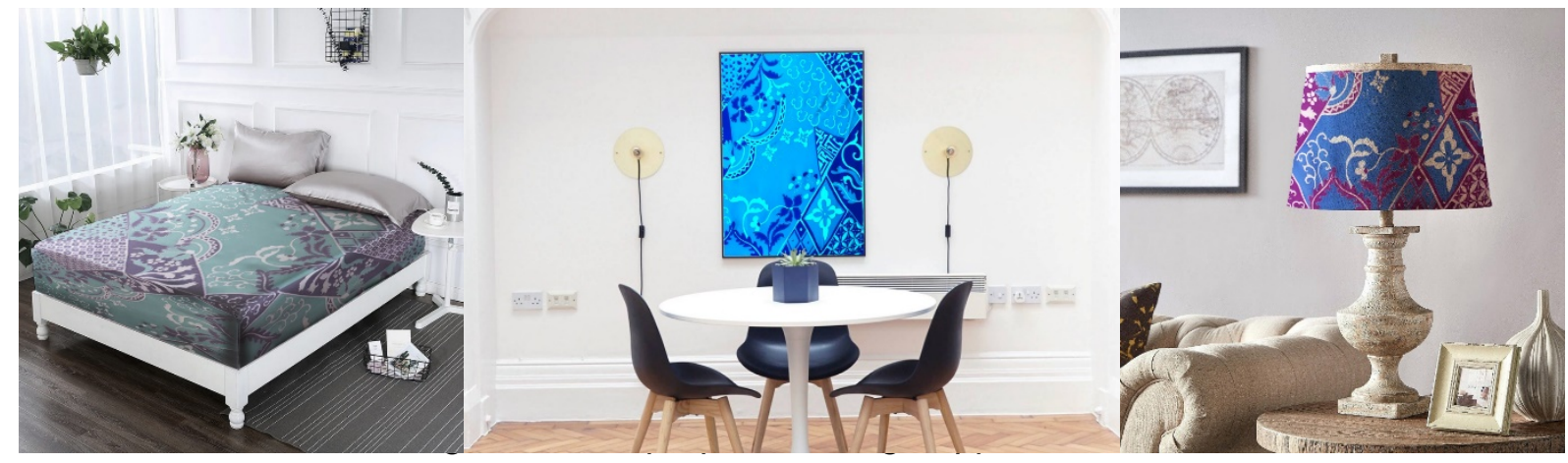

\section{CONCLUSION}

The integration of intercultural design of Malaysian textile motifs and Japanese textile motifs will increase international collaboration and its visibility in a global market. Thus, this study was conducted with the aim of integrating the Malaysian batik and Japanese textile motifs through product diversification which focus on home décor such as wall frame, table clothes, bed sheets and other home accessories. The proposed design was conducted to explore new design of the combined textiles motifs. The integration of Malaysian batik and Japanese textile motif is expected to facilitate the coverage of batik pattern and Japanese textile motifs in a global market. Besides, the proposed design might also contribute to the new opportunities for Malaysian batik and Japanese textile producers in expanding their handicrafts. In a broader aspect this collaborative textile industry will increase the economic growth of both countries as well as expanding the traditional textiles industry in worldwide.

\section{REFERENCES}

Ahmad Sayuti Nurul ‘Ayn, Mas Ayu Zainal @Ismail, Ahmad Fazlan Ahmad Zamri, Mohd Zamri Azizan. (2018). From Culture To Innovative Product:Batik Design In Porcelain Wares. Malaysian Journal of Sustainable Environment. 5(2). 27-42.

Aizat Khairi, Shamsul Effendy Abdul Hamid \& Shaiful Bakri Ismail. 2018. Penonjolan identiti budaya Melayu menerusi aplikasi batik dalam pembuatan bot gentian kaca (fibreglass boat) di Universiti Kuala Lumpur Malaysian Institute of Marine Engineering Technology (UniKL MIMET), Lumut, Perak. Wacana Seni Journal of Arts Discourse 17: 183-201. https://doi.org/10.21315/ ws2018.17.7.

Arney, S. (1987). Malaysia batik: Creating new traditions. Kuala Lumpur: Malaysian Handicraft Development Corp.

Aziz, A. (1990). Selayang kenangan. Kuala Lumpur: AMK Interaksi.

Bahasa dan Pustaka.

Baker, W. D., \& Baker, I. S. (1920). Batik and other pattern dyeing. Chicago: Atkinson, Mentzer \& Co. Baldick.

Crawfurd, J. (1820). History of the Indian Archipelago containing an account of the manners, arts, languages, religions, institutions, and commence of it inhabitants (Vols. 1-3). Edinburgh: Archibald Constable. Crawfurd.

Crawfurd, J. (1852). A grammar and dictionary of the Malay language, with a preliminary dissertation (Vols. 1-2). London: Smith, Elder, and Co. 
Dennys, N. B. (1894). A descriptive dictionary of British Malaya. London: Woodfall and Kinder.

Hussin, H. (2006). Motif alam dalam batik dan songket Melayu. Kuala Lumpur: Dewan Bahasa dan Perbadanan Kemajuan Kraftangan Malaysia Act, 1979. Kuala Lumpur: Percetakan Nasional Malaysia Berhad.

Ismail, S. Z. (1997). The traditional Malay handicraft design. Kuala Lumpur: Dewan

Kundharu Saddhono, Sahid Teguh Widodo, Muhammad Taufiq Al-Makmun \& Masakatsu Tozu. (2014). The Study of Philosophical Meaning of Batik and Kimono Motifs to Foster Collaborative Creative Industry. Asian Social Science; 10 (9). 52-61.

Legino, R. (2004). A study of the Islamic influences on traditional Malay batik sarongs of Kelantan and Terengganu (Master's thesis, University Technology MARA).

Legino, R. (2012). Malaysian Batik Sarongs: A Study of Tradition and Change, School OF Art RMIT Australia.

Leyden, J. (1821). Malay Annals translated from the Malay language by the Late Dr. John Leyden with an introduction, Sir Thomas Stamford Raffles, F.R.S. London: Longman.

Malaysian Handicraft, 2009. Malaysia Handicraft Development Corporation.

Mijer, P. (1919). Batiks, how to make them. NY, New York: Dodd, Mead and Company.

Muhammad Fitri Samsuddin, Siti Nurul Akma Ahmad, Mohd Hisham Johari, Azni Hanim Hamzah, Raziq Abdul Samat (2019). Promoting Malaysian "Batik" pattern through Automotive Interior Design. International Journal of Academic Research in Business and Social Sciences, 8(12), 20362043.

Pustaka. Hussin, N. (2008). Geography and trade: Importance of the Straits of Malacca to world trade, Asia and the Malay world 1700-1800. Akademika, 73, 3-26.

Rahab; Nurul Anwar; Supadi, Lasmedi Affuan, 2013. Promotion Mix Strategy For Improving Competitiveness of Batik Banyumasan, Proceeding on"3rd International Conference on Multidisciplinary Research (ICMR 2013), February, 7-9, 2013 in La Consolacion College, Bacolod City, Philiphina.

Sheppard, M. (1965). Malay courtesy: A narrative account of Malay manners and customs in everyday use. Singapore: Eastern Universities Press.

Slamet Supriyadi, Sariatun. (2016). Empowering "Girli" Batik Craftswomen to Enhance Family Economy and Develop Tourism Village in Sragen District. 3rd ISME International Colloquium.

Tanha, Mansoureh Rajabi \& Amad, Izmer. (2013). Towards a Cross Cultural Design by Integrating Batik Motifs into the Persian Carpet Design. International Journal of the Malay World and Civilisation. 1(1). 111-123.

Wardani, Laksmi Kusuma \& Sitindjak, Ronald Hasudungan Irianto. (2014). Batik and Its Implementation in Art and Design. The International Journal of Social Sciences. 24(1). 37-44. 